\title{
Неизвестный вариант первой Конституции Тувинской Народной Республики
}

\section{Аяна А. Самдан}

Тувинский институт гуманитарных и прикладных социально-экономических исследований при Правительстве Республики Тыва, Российская Федерация, Белекмаа В. Мунге, Марионелла М. Седип-оол Национальный архив Республики Тыва, Российская Федерация

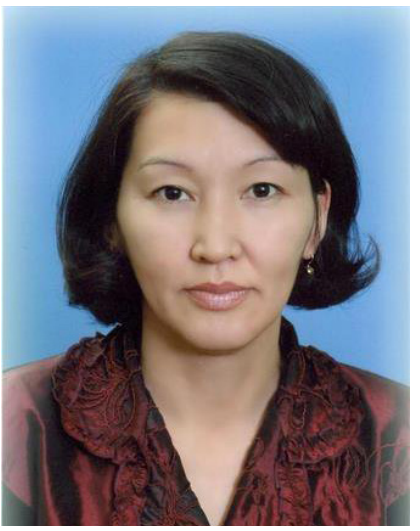

В статье вводится в научный оборот переведенный на русский язык текст старомонгольской рукописи «Постановление съезда семи хошунов Танну-[Тувы]». Она датируется 1921 г. Была найдена в 2021 г. в Национальном архиве Республики Тыва среди малоизученных документов.

Авторы полагают, что данный архивный документ является проектом первой Конституции (Основного закона) Тувинской Народной Республики, подготовленным группой тувинских участников Всетувинского учредительного хурала, которую возглавлял Буян-Бадыргы.

Даны характеристики архивного документа, предыстория его находки и полный текст в переводе.

Ключевые слова: конституция; Тува; история Тувы; Тувинская Народная Республика; хурал; Буян-Бадыргы

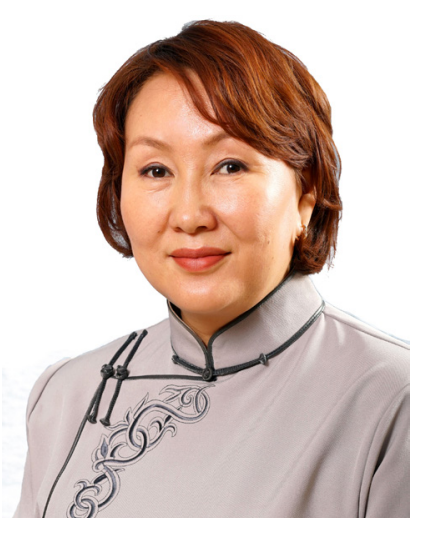

Для цитирования:

Самдан А. А., Мунге Б. В., Седип-оол М. М. Неизвестный вариант первой Конституции Тувинской Народной Республики // Новые исследования Тувы. 2021, № 3. C. 5-14. DOI: https://www.doi.org/10.25178/nit.2021.3.1

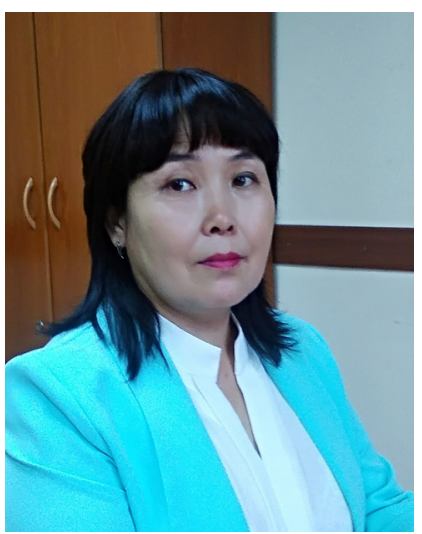

Самдан Аяна Анай-ооловна - кандидат исторических наук, ведущий научный сотрудник группы истории Тувинского института гуманитарных и прикладных социально-экономических исследований при Правительстве Республики Тыва. Адрес: 667000, Россия, г. Кызыл, ул. Кочетова, д. 4 . Тел: +7 (39422) 2-39-36. Эл. адрес: camayana@mail.ru

Мунге Белекмаа Владимировна - директор Национального архива Республики Тыва. Адрес: 667010, Россия, г. Кызыл, ул. Кечил-оола, д. 91. Тел.: +7 (394-22) 5-63-15. Эл. адрес: mungeb@ me.com

Седип-оол Марионелла Марий-ооловна - начальник отдела государственного учета и обеспечения сохранности архивных документов Национального архива Республики Тыва. Адрес: 667010, Россия, г. Кызыл, ул. Кечил-оола, д. 91. Тел.: +7 (394-22) 5-64-39. Эл. адрес: msedipool@ mail.ru

SAMDAN, Ayana Anai-oolovna, Candidate of History, Leading Research Fellow, Group of History, Tuvan Institute for the Humanities and Applied Socioeconomic Research under the Government of the Republic of Tuva. Postal address: 4 Kochetov St., 667000 Kyzyl, Russian Federation. Tel.: +7 (39422) 2-39-36. Email: camayana@mail.ruＯRCID ID: 0000-0002-7785-7497 MUNGE, Belekmaa Vladimirovna, Director, National Archives of the Republic of Tuva. Postal address: 91 Kechil-ool St., 667010 Kyzyl, Russian Federation. Tel.: +7 (394-22) 5-63-15. E-mail: mungeb@me.com ORCID ID: 0000-0002-4432-4395

SEDIP-OOL, Marionella Marij-oolovna, Head, Department of Management and Preservation of Archival Documents, National Archives of the Republic of Tuva. Postal address: 91 Kechil-ool St., 667003 Kyzyl, Russian Federation. Tel.: +7 (394-22) 5-64-39. E-mail: msedipool@mail.ru 


\title{
An unknown version of the first Constitution of Tuvan People's Republic
}

Article

\author{
Ayana A. Samdan \\ Tuvan Institute for the Humanities and Applied Socioeconomic Research \\ under the Government of the Republic of Tuva, Russian Federation,
}

Belekmaa V. Munge, Marionella M. Sedip-ool

National Archives of the Republic of Tuva, Russian Federation

\begin{abstract}
The article introduces a translation of a previously unknown manuscript in Old Mongolian titled "The resolution of the assembly of the seven khoshuuns of Tannu[-Tuva". Dated 1921, it was found a century later - in 2021 - among the little-studied materials at the National Archives of the Republic of Tuva.

The authors argue that this archival document is the draft version of the first Constitution of the Tuvan People's Republic prepared by a group of Tuvan delegates of the All-Tuvan Constitutional Khural, led by Buyan Badyrgy.

The article provides a description of the document, the history of its discovery and its full text (in translation).
\end{abstract}

Keywords: constitution; Tuva; history of Tuva; Tuvan People's Republic; khural; Buyan-Badyrgy

For citation:

Samdan A. A., Munge B. V. and Sedip-ool M. M. Neizvestnyi variant pervoi Konstitutsii Tuvinskoi Narodnoi Respubliki [An unknown version of the first Constitution of Tuvan People's Republic]. New Research of Tuva, 2021, no. 3, pp. 5-14. (In Russ.). DOI: https://www.doi.org/10.25178/nit.2021.3.1

\section{Введение}

В 2021 г. Республика Тыва отмечает две важные даты: 100 лет со дня образования Тувинской Народной Республики (ТНР) и 100-летний юбилей первой Конституции, принятой 15 августа на Всетувинском учредительном хурале в местечке Суг-Бажы. Многие события тех времен получили свое отражение в монографических исследованиях, научных публикациях и документальных сборниках трудов, но и в настоящее время вопрос по Конституции Тувы остается актуальным.

Сегодня имеется целый ряд публикаций, касающихся истории разработки и принятия первой Конституции ТНР, протокола Всетувинского учредительного хурала (август 1921 г.), которые отражены в работах историков-тувиноведов и юристов (Аранчын, 1982; Дубровский, 1958; Сат, 2000; Ондар, 2002, 2009; Моллеров, 2019, 2020).

Впервые сборник конституций периода ТНР вышел в третьем выпуске в трудах Научно-исследовательской ассоциации по изучению национальных и колониальных проблем в 1934 г. в Москве 1 . Автором составителем стал Б. Аюшин. Сборник в настоящее время хранится в научно-справочной библиотеке Национального архива Республики Тыва (НА РТ) и содержит тексты Конституций Тувы на

${ }^{1}$ Государственный строй Тувинской Народной Республики (Сборник материалов и документов) / сост. Б. Аюшин / Научно-исследовательская ассоциация по изучению национальных и колониальных проблем. Серия учебных пособий. Вып III. М.: б. и. 55 с. 
русском языке 1921, 1924, 1926, 1930 гг., общее положение о министерствах ТНР, положения о хошунных, сумонных хуралах и управлений, положение об арбанах ТНР.

Позднее сборник конституций Тувы был опубликован отдельной брошюрой в работе В. А. Дубровского (Создание суверенного ..., , 1991; Конституции Тувы, 1999), а также в архивных сборниках, изданных Государственным (ныне - Национальным) архивом Республики (Создание суверенного ... , 1991; Конституции Тувы ..., 1999; История Тувинской ..., 2011: 7-17).

В научных работах исследуется русский вариант Конституции ТНР 1921 г., вместе с тем в протоколе Всетувинского учредительного хурала (НА РТ, ф. 93, оп. 1, д. 2, лл. 1-15) имеется заявление БуянБадыргы «мы, хемчикские хошуны, еще дома выработали свою Конституцию...». Эта фраза вызывает вопрос: значит есть другой проект - первая Конституция на старомонгольской письменности?

В свое время В. А. Дубровский, по нашему мнению, являясь директором архива (1949-1962 гг.), при подготовке своих публикаций (Маадыр, 2020: 35-36), предпринимал попытки поиска всех вариантов Конституции (Конституции Тувы ..., 1999: 24). Возможно, причиной отсутствия исторического документа стало несовершенное управление делопроизводством, утрата или уничтожение архивных документов.

Но история поиска подлинника первой Конституции на старомонгольской письменности продолжилась в 2019 г., когда по инициативе д-ра филол. н. К. А. Бичелдея, директора Национального музея им. Алдан-Маадыр Республики Тыва, была запланирована совместная рабочая командировка с одним из соавторов данной статьи Б. В. Мунге, директором Национального архива РТ, в Национальный архив Монголии. Мы предполагали, что интересующий нас документ может быть там. К сожалению, попытка не увенчалась успехом - поездка не состоялась, а с наступлением пандемии и вовсе отложилась.

Несмотря на это, поиски варианта Конституции 1921 г. и в самом НА РТ продолжались. По заданию руководства архива, в процессе работы с монгольскими рукописями начальник отдела государственного учета НА РТ М. М. Седип-оол обнаружила неизвестный ранее рукописный текст на старомонгольской письменности, без перевода под названием «Постановление съезда семи хошунов Танну[Тувы]» (НА РТ, ф. 115, оп., 1, д. 249, лл. 14-20), который впоследствии перевела к. и. н. А. А. Самдан.

Авторы статьи полагают, что найденная рукопись была составлена во время или после Всетувинского учредительного хурала тувинскими участниками во главе с М. Буян-Бадыргы.

\section{Характеристики документа}

Подлинная рукопись под названием «Постановление съезда семи хошунов Танну-[Тувы]» (НA PT, ф. 115, оп. 1, ед. хр. 249, лл. 14-20) датируется 1921 г.

Документ состоит из введения и 38 статей Конституции (Основного закона) Танну-Тува, без подписи.

Рукопись написана на китайской тонкой бумаге. Состояние рукописи удовлетворительное, имеющиеся дефекты без утраты текста: осыпание и незначительные разрывы краев листов, потемнение бумаги от естественного процесса старения документа.

Текст рукописи написан на старомонгольской письменности классическим монгольским письмом (монгол бичиг), выполнен каламом и черной тушью. Рукопись имеет книжный формат, из сформированной и сложенной вдвое бумаги, общий объем -7 листов. Пагинация отсутствует. Количество строк по листам 16-17 строк. Листы между собой закреплены (прошиты) такой же тонкой бумагой в несколько слоев. В тексте имеются разные пометки, подчеркивания синими чернилами. На 3 стр. имеется приписка синими чернилами «орус -13 , моол -4 , тыва -53 , толээ -70 » (русских -13 , монгол -4 , тувинцев -53 , всего представителей -70$)$, написанная скорее всего переводчиком, которой вел подсчет представителей совещания по национальной принадлежности.

На титульном листе в центре дано название рукописи, в верхней части листа синими чернилами имеются пометки «Инвен № 28» и «5/166», а также роспись зеленым карандашом на латинизированном алфавите (латинизированном на новотюркской основе) «Occuldurgan» (очулдурган, т. е. «переведен»).

Рукопись хранится в составе архивных документов 115 фонда «Управления амбын-нойона ТаннуУрянхая» (НА РТ, ф. 115; 339 ед. хр., 1715-1933 гг.), который был сформирован в 1956 г. из объединенных фондов ф-26 «Правитель Урянхайского края князь кунь-найон» и ф-27 «Управляющий Да хошуном (Кемчикским) Урянхайского края (1896-1917 гг.)» (НА РТ, дело фонда 115, л. 19). 
Документ находится в деле 249 под названием «Первый Всетувинский учредительный революционный съезд - шуулган 7 хошунов Танну-Тувы с представителями Советской России и Монголии в местечке Суг-Бажы (протокол, постановления)».

В результате поисков в фонде 246 «Архивного агентства Республики Тыва» (НА РТ, ф. 246; 742 ед. хр., 1944-2015 гг.), была найдена инвентаризационная ведомость (с. 27-32) приемо-сдаточного акта со 2 по 4 ноября 1945 г., согласно которой данная рукопись числилась под номером 28 «Тываның 7 кожуунунуң чөвулел хуралы» (Постановление съезда 7 хошуунов Тувы. - перевод Б. В.), 1921 г., что соответствует пометке на первом листе рукописи.

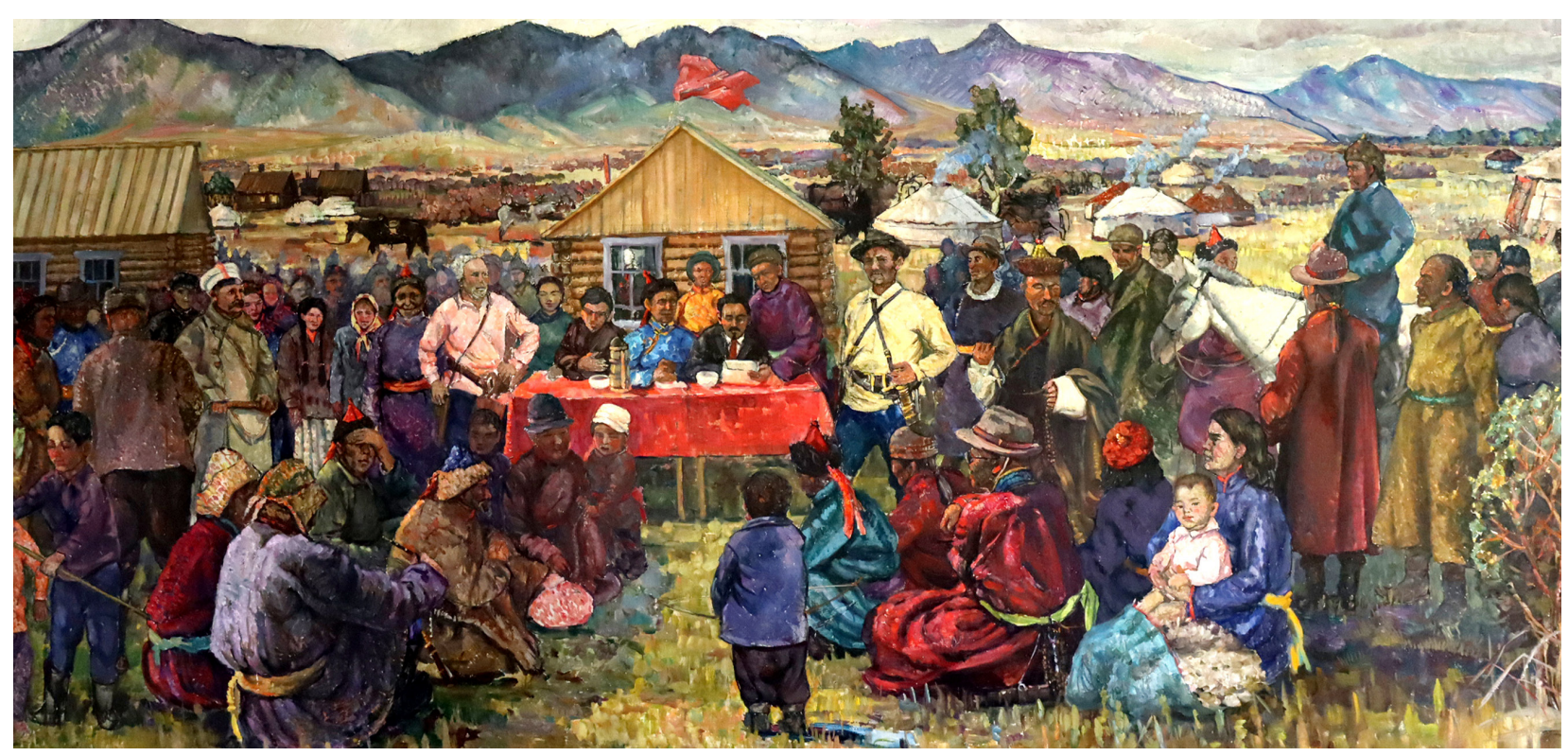

Рис. 1. Картина «Всетувинский хурал» заслуженного художника Тувинской АССР Г. Суздальцева, 1981 г. Хранится в Историко-мемориальном филиале Национального музея им. Алдан-Маадыр Республики Тыва в с. Кочетово Тандинского района.

Fig. 1. Fragment of the painting "All-Tuvan Khural” by honored artist of Tuvan ASSR G. Suzdaltsev, 1981. The Aldan Maadyr National Museum of Tuva, Historical and Memorial Office in Kochetovo, Tandy Kozhuun.

\section{Цифровые образы документа}

В настоящее время в Национальном архиве Республики Тыва хранится 1441 фонд, 277802 ед. хр., из них 6256 ед. хр. отнесены к разряду особо ценных документов ${ }^{1}$.

В том числе НА РТ обладает уникальным рукописным фондом старомонгольских документов, которая насчитывает 2512 ед. хр. При этом перевод осуществлен только 352 документов, т. е. 14\% всего объема. Учитывая это, можно предположить и последующие открытия содержаний документов архива.

В НА РТ хранятся следующие Конституции Тувы:

1. «Конституция Республики Танну-Тува Улус, принятая 15 августа 1921 г. на I Великом Хурале ТНР», машинописный текст, на русском языке (НА РТ, ф. П-1, оп. 1, д. 26, л. 1-2, д. 28, л. 1-2; ф. 93, оп. 1, д. 3, л. $1-2)$,

2. Конституция Тувинской Народной Республики, принятая в октябре 1924 года, машинописный текст, на русском языке (НА РТ, ф. П-1, оп. 1, д. 88, л. 1-2) на старомонг. письм. (НА РТ, ф. 144, оп. 2, д. 30, л. 1-3),

\footnotetext{
${ }^{1}$ Согласно п. 5. ст. 3 Федерального закона от 22.10.2004 г. № 125 «Об архивном деле в Российской Федерации» особо ценный документ - документ Архивного фонда Российской Федерации, который имеет непреходящую культурно-историческую и научную ценность, особую важность для общества и государства и в отношении которого установлен особый режим учета, хранения и использования.
} 
3. Проект Конституции 1923 г. на старомонгольской письменности (НА РТ, ф. 144, оп. 1, д. 3, л. 13-17),

4. Конституция (Основной закон) THP, принятая IV Великим Хуралданом THР 24 ноября 1926 г.», машинописный текст, на русском языке (НА РТ, ф. П-1, оп. 1, д. 268, л. 1-7; ф, 144, оп. 1, д. 26, л. 1-17 (старомонг. письм); «Конституция Тувинской Народной республики /ТНР/ /Основной закон/, утвержденная на заседании IV Великого Хуралдана THP от 24 ноября 1926 года», машинописный текст, на русском языке (НА РТ, ф. П-1, оп. 1, д. 269, л. 1-7),

5. «Постановление VII Великого Хуралдана ТНР об Утверждении Основного закона /Конституции/ ТНР, Основной закон/ Конституция/ТНР. 1930 г.», машинописный текст, на русском языке (НА РТ, ф. П-1, оп. 1, д. 874, л. 1-18, д. 875, л. 1-16 (брошюра), ф. 92, оп. 1, д. 47, л. 1-8 (машиноп. тув. лат.)),

6. «Конституция (Основной закон) Тувинской Народной Республики», принята XI (X) Великим Хуралом ТНР 25 июня 1941 г. ${ }^{1}$ (НА РТ, ф. 93, оп. 1, д. 223, л. 1-19; ф. П-1, оп. 1, д. 2631, л. 1-16 (машинопис. тув. лат.); д. 2632, л. 1-12 (на русс. яз.); д. 2633, л. 1-27 (брошюра на машин. тув. лат.),

7. «Конституция (Основной закон) Тувинской Автономной Советской Социалистической Республики» 1978 г. (НА РТ, ф. 285, оп. 1, д. 585, лл. 5-53, д. 593, лл. 129-172).

Последующие тексты конституций были опубликованы в различных изданиях, которые хранятся в научно-справочной библиотеке НА РТ:

1) «Конституция (Основной закон) Республики Тыва», 1993 г. ${ }^{2}$,

2) «Конституция Республики Тыва», 2001 г. ${ }^{3}$

К этому списку теперь добавится и найденный документ, свидетельствующий о том, как серьезно готовились к принятию самого первого основного закона государства сами тувинцы.

\section{Тувинский вариант первого Основного закона ТНР}

Приводим полный текст найденного документа, переведенный А. А. Самдан.

«Постановления съезда семи хошунов Танну-[Тувы]

От Советской России представитель Сибревкома Иннокентий Сафьянов, председатель русских [жителей, проживающих] в Туве Стрелков, заместитель Сухорослов, военный комиссар Чугунов, командир военных, дислоцированных в Туве Кочетов, чиновник министерства Квитный, дипломатический чиновник Медведев, чиновники министерства Сафьянов, Терентьев, заведующий русским [населением] северной частью Танну-Ола Сафьянов, заведующие русским [населением] южной частью Хема Макаров, Сафьянов, заведующий русским [населением] западной частью Могоя - Власов, заведующий русским [населением] Тоджи - Сухомилинов, заведующий делами русских Старков, представитель от русского народа - Сафьянова.

От Монгольского Народного Правительства старший чиновник (в тексте - түшмэл. - A. С.) Чагдуржав, чиновники - Цэвэнжав, Боровиков, Мартинелли.

От Танну-[Тувы] Хемчик-гольского 17 сумонов, хошунов: бээзи ${ }^{4}$ Чымба из Куулар сумона, дэмчи ${ }^{5}$ Седенжав, дузалакчы Ананды из Хертек-Соян сумона, правитель Соном-Байыр из Кыргыс сумона, мээрен $^{6}$ Сагаачы, чайзан ${ }^{7}$ Балган, правитель Сонам из Адыг-Тулуш сумона, чалан ${ }^{8}$ Басан, дагалт ${ }^{9}$ Сүрүнмей, правитель Борбак-оол из Тумат сумона, чайзан Байыр из Долаан сумона, дэмчи Хеликей, чайзан Саая из сумона Улуг-Тулуш, чалан Тыкыр, мээрен Езуту из Салчак сумона, чангы ${ }^{1}$ Дондук из Кужугет сумона, правитель Серен-Дондук из Донгак сумона, мээрен Дондук из Чааты-Донгак, чалан Түмендей, чайзан Балчыр из Сат сумона.

${ }^{1}$ Сборник законов ТНР. Кызыл: Тувинское книжное издательство, 1944. С. 15-27.

${ }^{2}$ Конституция (Основной закон) Республики Тыва. 1993 г. Кызыл : Издательство Верховного Совета Республики Тыва, 1993. 60 с.

${ }^{3}$ Конституция (Основной закон) Республики Тыва 2001 г. Кызыл : Типография Госкомитета по печати Республики Тыва, 2001.67 с.

${ }^{4}$ Бээзи (монг. бэйс) - князь четвертой степени.

5 Дэмчи - сборщик податей, надзиратель, помощник монастырского казначея, староста, начальник.

${ }^{6}$ Мээрен - командир соединения.

7 Чайзан (маньч.) - управитель отока, глава рода.

8 Чалан (монг. залан) - командир полка.

${ }^{9}$ Дагалт (монг.) - свита, слуга. 


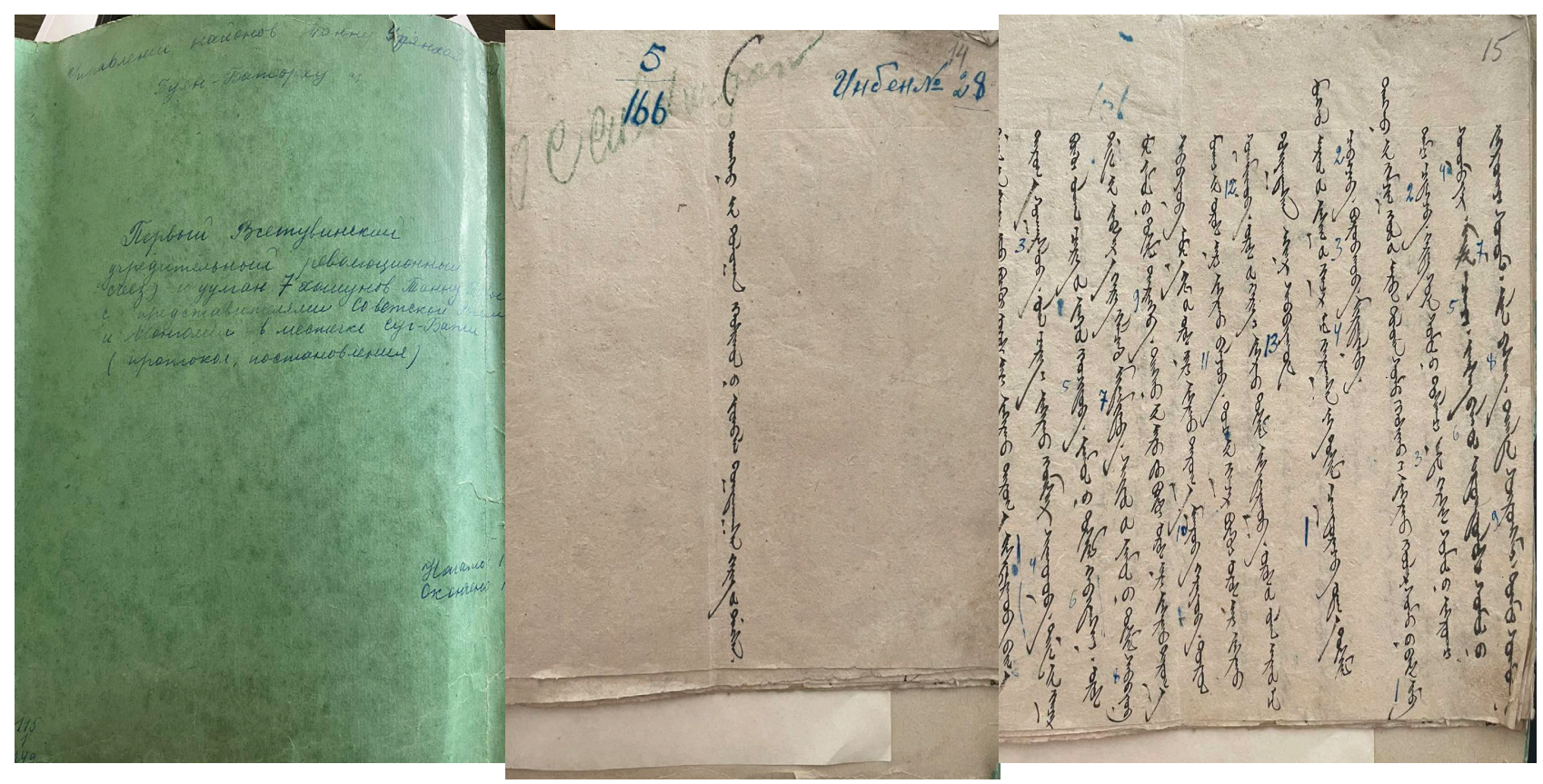

Рис. 2-4. Обложка папки с документом из фондов Национального архива Республики Тыва, его титульный лист и одна из страниц.

Fig. 2-4. The cover of a document preserved at the National Archives of the Republic of Tuva, its title page and one of the pages of the text.

От Хемчик-гольского 10 сумонов: эрдэнэ-бээзи Буян-Бадыргы из Монгуш сумона, правитель Бадыргы, правитель Нармандагы из Ондар сумона, чангы Кичээ, правитель Назыты из Улуг-Ооржак сумона, чангы Баян из Биче-Ооржак сумона, хунду² Баясгалан из Саая сумона.

От Салчак хошуна: правитель Кунгаа из Салчак сумона, чангы Даваа, чалан Бүрбү, мээрен Чамзы из Кыргыс сумона, Довчид, мээрен Чанзан из Байкара сумона, хунду Чанзан, чалан Сүрен из Нуур сумона.

От Тоджинского хошуна: мээрен Лувсан из главного сумона, гэвгүй ${ }^{3}$ Дуганчы из Ак-Чооду сумона.

От Оюннар хошуна: бээзи Ажыкай, да-лама Балдар, дузалакчы Дарма-Базар, правитель Демир, Сундуй, чалан-чангы Мөнге, мээрен Со-хөө Аракай, чангы Данзын, хунду Чапсырай, гэлун Чыргалан, дарга Онмид.

От Маады хошууна: правитель Лопсан-Осур, чайзан Сайн-Белек, хунду Соксур-Барам из Чооду сумона, правитель Шалык сумона Чалзырай, чангы Раши

В 1921 году седьмой месяц 2-го дня

Год беловатой курицы седьмого месяца начиная со 2 дня и до 14 дня этого же месяца на Всеобщем съезде постановили.

1. На местах отменяется старая реакционная власть, и сообщаем народу об установлении самостоятельного государства, а также требуем не противодействовать [этому].

2. Танну-Тува не входит ни в одно государство, образует единое независимое государство (в тексте чуулган - сейм. - A. C.), самостоятельный во внутренних делах, но в международных сношениях выступает под покровительством Советской России.

3. Принятые всеобщм решением постановления подлежат исполнению одинаково всеми.

\footnotetext{
${ }^{1}$ Чангы (монг. занги) - командир эскадрона, правитель сумона, уртона.

${ }^{2}$ Хунду - помощник правителя сумона.

${ }^{3}$ Гэвгүй (тиб.) - блюститель порядка во время богослужения в монастыре.

${ }^{4}$ Данный раздел с небольшими изменениями совпадает с вводной частью протокола Всетувинского учредительного хурала, в котором была принята Конституция Танну-Тува Улус (13-16 августа 1921 г.).
} 
4. С этого момента необходимо заботиться о просвещении [народа] ${ }^{1}$.

5. Тувинцам [предоставляется право] исповедовать [любую] религию по своему усмотрению. Монахи, постоянно живущие в монастырях, и худонские ламы сохраняют свой прежний статус ${ }^{2}$.

6. Начать подготовку [строительства учреждений] здравоохранения 3 .

7. Начать подготовку создания государственного бюджета.

8. Отменяется применение пыток по отношению к преступным личностям. В качестве наказания применяется заключение в тюрьму, а также в соответствии с наказанием конфискация имущества с виновного в пользу казны.

9. С этого момента русские и тувинцы совместными усилиями изгоняют белых русских и других иностранных захватчиков.

10. Съезд Тувы собирается один раз в год и принимает решения по всем вопросам.

11. На съезд делегируются от каждого сумона один депутат (в тексте түшмэл. - A. С.) и от бага, сумона - по два депутата.

12. Создать Совет (в тексте чуулган - съезд, сейм - A. C.) $)^{4}$ Танну-Урянхая в центральной части страны, от каждого хошуна делегируется один представитель (в тексте түшмэл. $-A$. С.). Между сессиями Совета [по очереди один из членов Совета] принимает решения по всем возникающим вопросам.

13. По любым сложным внутренним вопросам Совет самостоятельно принимает решение. В случае переговоров с иностранным государством, то также принимает совместное решение.

14. Если принятое решение не будет исполнено (букв. 'переведено, передано’. - A. С.), то этого чиновника следует наказать.

15. Члены Всеобщего Совета для обсуждения накопившихся дел собираются один раз в квартал. В случае необходимости может быть объявлен внеочередной Совет.

16. [Во время сессии] Совета необходимо вызвать для работы писаря, курьера и бошго 5

17. По-старому организовать очередную службу хошунов с дежурством чиновника и писаря из 3 человек, которые принимают решения по внутренним вопросам и заседают два раза в год.

18. Каждый сумон управляется [Советом] из трех человек.

19. 3 лица очередной службы от каждого хошуна вызывают из своего хошуна должностных лиц и аратов, необходимых для ведения административных дел.

20. Все должностные лица утверждаются только на Съезде, никак в другом месте.

21. Если возникнет вопрос о несении службы от сумона, то его должен решить Совет из трех чиновников.

22. Сумонные чиновники подчиняются хошунным чиновникам. Хошунные должностные лица подчиняются Совету. Ни одно должностное лицо не должен уклониться от данной установленной нормы.

23. Внутрихошунными делами заведует хошунный чиновник. Внутрисумонными - сумонный чиновник. Дела, не подчиняющиеся хошунным и сумонным чиновникам, решает Совет.

\footnotetext{
${ }^{1}$ Правительство молодой республики взял курс на создание светского образования в Туве. В старой Туве буддийские монастыри были единственными очагами просвещения.

${ }^{2}$ Здесь имеется в виду освобождение от уплаты повинностей. В принятом варианте Основного закона 1921 г. эта статья содержала более обширное определение. «Духовенство и сословие ховраков, занимающиеся хлебопашеством и скотоводством, несут одинаково все общественные повинности и потому могут наравне с другими гражданами занимать общественные должности. Духовенство, не занимающееся хозяйством, а живущее на средства, получаемые от богослужения, не пользуется правом вмешательства в гражданские дела и не несет никаких повинностей» (Создание суверенного ..., 1991: 78).

${ }^{3}$ B начале XX в. в Туве практически отсутствовали европейские учреждения здравоохранения. Здесь была распространена тибетская медицина, а также обращались к шаманам, которые изгоняли «духов».

${ }^{4}$ В другом месте дан как Всеобщий Совет (см. здесь ст. 15, 23).

${ }^{5}$ Бошго (монг., тув.: бошка) - низший чиновник.
} 
23로. Во Всеобщий Совет Танну-Тувы делегируется один представитель из семи хошунов. Из них избирается председатель Совета, который руководит делами республики (в тексте аймака. - A. С.).

24. Также из девяти хошунов Танну-[Тувы] Хасутский хошун находится в отдаленности, а два сумона Шалык и Сартуул слишком малочисленны, поэтому из этих двух сумонов образовать один хошун, всего в Танну-[Туве] образовать семь хошунов.

25. Постановили, что назначенные должностные лица Совета должны собраться со всеми необходимыми вещами первого числа 9 месяца и обосноваться в населенном пункте около местечки ХемБелдир.

26. На территории Тувы проживают 10300 русского населения в 38 поселках в дружественной обстановке с местным населением. Их считать автономной ${ }^{2}$ во внутренних делах и [управлении]. Живут по своим законам, но русско-тувинские взаимоотношения решают совместно сайд ${ }^{3}$ Советской России и председатель Совета Тувы.

27. Постановили, что помимо проживающих на территории Тувы в 38 поселках русских запрещается новое заселение.

28. На территории Танну-Тувы запрещается иностранным государствам добывать месторождения золота, серебра, железа, соли и др. Если же будут добывать советские граждане, то добыча возможно только с разрешения местных руководителей, при этом не причинять урон пастбищам, местному населению и после взыскания установленного сбора. Запрещается добывать сверх установленной нормы. Также проживающим на территории Тувы русским разрешается охотиться, рыбачить только в пределах своих нужд. Запрещается охотиться сверх количества с целью личного обогащения и продажи. Постановили, что разрешается охотиться на территории Тувы и России.

29. Постановили выселить русских, проживающих на территории Танну-Тувы, связанных с белыми русскими.

30. Постановили аннулировать все иски по ранее возникшим преступным делам между русскими и тувинцами. Но возвращению подлежат предоставленные тувинцами 20 числа шестого месяца этого года лошади, провизии, седла, уздечки, веревки и др., взятые русскими военными. В случае уничтожения - решено взыскать с последних. В дальнейшем, в случае возникновения подобных недоразумений между русскими и тувинцами, необходимо сообщить в советские учреждения и принимать совместные решения.

31. Советская торговля организуется в восьми местах: Хем-Белдир, Туран, Тоора-Хем, Сарыг-Сеп, Самагалтай, Шагаан-Арыг, Чанагаш, Чыдыг-Кара-Суг. Для охраны товаров выделяется небольшой военный отряд, а необходимый фураж можно будет заготовить вблизи этой местности. Запрещается заселение новых русских торговцев, а проживающим в [Туве] русским - нельзя их брать на поселение.

Также запрещается торговцам заниматься хлебопашеством.

Также русско-тувинская торговля должна быть основана на взаимозачете. Если продадут в долг неимущему человеку, то [иск] не будет рассмотрен. Также если тувинец будет продавать скот советскому торговому учреждению, то оплату производить советскими новыми целковыми ${ }^{4}$ монетами. Когда в торговую лавку привезут товар, то согласно договоренностей, следует сдать эти денежные средства и обменять на товар. Постановили, что в случае возникновения конфликтных ситуаций нельзя заставить человека вернуть деньги.

Должностные лица местных сумонов договорившись о времени и месте [оплаты] могут взять [товар] в долг и в срок произвести оплату пушниной. Также в случае, если стоимость товара иностранного торговца равноценно с ценой товара советского торгового учреждения, то пушнину следует сдать в советское торговое учреждение. Если окажется, что цена дороже, то разрешается покупать более дешевый товар.

\footnotetext{
${ }^{1}$ В тексте нумерация повторяется.

2 Вопрос взаимоотношения тувинцев и русских стоял отдельным вопросом в повестке дня Всетувинского учредительного хурала. После обсуждения съезд постановил: «Находящееся на территории Танну-Тува русское население в количестве 10300 человек считается русской Советской автономной колонией, живущей по Конституции Советской России и ей непосредственно подчиненной» (Создание суверенного ..., 1991: 82).

${ }^{3}$ Сайд (монг.) - министр, сановник.

${ }^{4}$ Целковый - денежная единица Российской империи, серебряная монета достоинством в один рубль.
} 
32. Если тувинец совершит [какой-либо] проступок, то русским запрещается, как прежние времена, избивать его и заключать в тюрьму. Постановили, что следует их доставлять в местное управление. Соответственно, подобным образом следует поступать и по отношению к русским. Также постановили, что без письменного разрешения от председателя Совета запрещается предоставлять русским уртонных лошадей.

33. Поскольку было решено, что с проживающим на территории Танну-Тувы в 38 поселках русским населением жить в дружбе, то договорились о том, что русские Правительству Танну-Тувы ежегодно выделяют муку, сено и дрова. Поскольку в этом году урожай пшеницы вырос в недостаточном количестве, то выделят муки - 900 пудов, сена -300 кубов, дров - 24 сажени [с условием] возврата на следующий год.

34. Русские должны оградить сельскохозяйственные угодья с тем, чтобы скот не уничтожил урожай. Постановили, что также тувинцы позаботятся не пускать скот на посеянные площади.

35. Постановили, что тех аратов, которые постоянно и многократно допускают рецидивное преступление, не перевоспитываются, следует наказывать очень строго. Также постановили вызвать всех, допустивших рецидив и [по решению] председателя Совета заключить их в тюрьму на срок 1-2 года ${ }^{1}$.

36. Раньше тувинцы свои земли для сенокоса продавали русским. С этого момента запрещаются подобные действия. Если, как и раньше, будут продавать или сдавать [в аренду], то постановили отдать правосудию.

37. Раньше между русскими и тувинцами постоянно возникали недоразумения по поводу потравли сельскохозяйственных угодий, что служило поводом самоуправно отнимать скот и избивать людей. Сейчас полностью запрещаются подобные действия, в последующем, если скот проникнет в сельскохозяйственные угодья, то его огородить и передать хозяину. Затем сообщить русским и тувинским должностным лицам, которые, осмотрев место, должны принять совместное решение.

38. Постановили оставить [иностранцев], проживающих на территории Тувы.

\section{Заключение}

Таким образом, вводя в научный оборот текст найденного нами документа - варианта первой Конституции Тувинской Народной Республики 1921 г. на старомонгольской письменности, подготовленный группой активистов во главе с Буян-Бадыргы, мы надеемся активизировать исторические исследования этого периода истории Тувы. Мы полагаем, что открываются дополнительные возможности для более глубокого исследования истории ТНР, раскрываются новые детали картины событий 14-16 августа 1921 г.

\section{СПИСОК ЛИТЕРАТУРЫ}

Аранчын, Ю. Л. (1982) Исторический путь тувинского народа к социализму. Новосибирск : Наука. 337 с.

Дубровский, В. А. (1958) Конституции Тувинской Народной Республики // Ученые записки. Вып. VI. Кызыл: Тувинское книжное издательство. 307 с. С. 276-304.

История Тувинской Народной Республики в архивных документах 1921-1944 гг. (2011) / А. М. Дугар-Сюрюн. Новосибирск : Сибирское книжное изд-во. 312 с.

Конституции Тувы 1921-1993 гг. (1999) : сборник к 55-летию принятия Тувы в состав СССР и РСФСР / сост. В. А. Дубровский. Кызыл : Тувинское книжное издательство. 216 с.

Маадыр, М. С. (2020) История становления археографии Тувы // Новые исследования Тувы. № 2. С. 32-46. DOI: https://www.doi.org/10.25178/nit.2020.2.2

Моллеров, Н. М (2019) Хуралы - органы представительной и законодательной власти ТНР (к изучению проблемы) // Вестник Тувинского государственного университета. №1 Социальные и гуманитарные науки. № 3 (48). C. 50-58.

\footnotetext{
${ }^{1}$ Принцип разделения властей не соблюдался, если законодательная и исполнительная ветви власти были разделены, то судебная власть была совмещена с исполнительной.
} 
Моллеров, Н. М. (2020) Великий Хурал - высший и представительный орган власти Тувинской Народной Республики // Новые исследования Тувы. № 3. С. 4-19. DOI: https://www.doi.org/10.25178/nit.2020.3.1

Ондар, Н. А. (2002) Государственное строительство в Республике Тыва: история и современность. М. : Изд-во науч.-образоват. лит-ры РЭА им. Плеханова. 236 с.

Ондар, Н. А. (2009) Конституционное развитие Республики Тыва (история и современность). Абакан : ГУП «Полиграфическое предприятие «Хакассия». 512 с.

Сат, С. Ч. (2000) Формирование и развитие политической системы Тувинской Народной Республики, 1921-1944 гг. : дисс. ...... и. н. Иркутск. 215 с.

Создание суверенного государства в Центре Азии. Протоколы хуралов 1912 года (1991) / сост., публикация и автор «Введения» В. А. Дубровский. Бай-Хаак : б. и. 96 с.

Дата поступления: 15.07.2021 г.

\section{REFERENCES}

Aranchyn, Yu. L. (1982) Istoricheskii put' tuvinskogo naroda $k$ sotsializmu [The historical path of the Tuvan people to socialism]. Novosibirsk, Nauka. 337 p. (In Russ.).

Dubrovskii, V.A.(1958) Konstitutsii Tuvinskoi Narodnoi Respubliki [Constitutions of Tuvan People’s Republic]. Uchenye zapiski. Vol. VI. Kyzyl, s. n. Pp. 276-304. (In Russ.).

Istoriya Tuvinskoi Narodnoi Respubliki v arhivnykh dokumentakh 1921-1944gg [The History of the Tuvan People's Republic in archival documents, 1921-1944] (2011). Ed. by N. M. Mollerov and A. M. Dugar-Surun. Novosibirsk, Sibirskoe knizhnoe izdatelstvo. 312 p. (In Russ.).

Konstitutsii Tuvy [Constitutions of Tuva] (1999): a collection published for the 55th anniversary of Tuva's accession to the USSR and RSFSR. Kyzyl, Tuvan book publishing house. 216 p. (In Russ.).

Maadyr, M. S. (2020) Istoriia stanovleniia arkheografii Tuvy [The rise and history of archaeography in Tuva]. New Research of Tuva, no. 2, pp. 32-46. DOI: https://www.doi.org/10.25178/nit.2020.2.2

Mollerov, N. M. (2019) Khuraly - organy predstavitel'noi i zakonodatel'noi vlasti TNR (k izucheniiu problemy) [Khurals as representative and legislative bodies of the TPR]. Vestnik Tuvinskogo gosudarstvennogo universiteta, Issue 1. Sotsial'nye i gumanitarnye nauki, no. 3 (48), pp. 50-58. (In Russ.).

Mollerov, N. M. (2020) Velikii Khural - vysshii i predstavitel'nyi organ vlasti Tuvinskoi Narodnoi Respubliki [The Great Khural as the supreme representative authority of the Tuvan People's Republic]. New Research of Tuva, no. 3, pp. 4-19. (In Russ.). DOI: https://www.doi.org/10.25178/nit.2020.3.1

Ondar, N. A. (2002) Gosudarstvennoe stroitel'stvo v Respublike Tyva: istoriia i sovremennost' [The construction of a state in the Republic of Tyva: history and modernity]. Moscow, Izd-vo nauch.-obrazovat. lit-ry REA im. Plekhanova. 236 p. (In Russ.).

Ondar, N. A. (2009) Konstitutsionnoe razvitie Respubliki Tyva (istoriia i sovremennost') [Constitutional development of the Republic of Tyva: history and modernity]. Abakan, GUP «Poligraficheskoe predpriiatie «Khakassiia». 512 p. (In Russ.).

Sat, A. K. (2006) Formirovanie i razvitie kadrovogo potentsiala Tuvy (1921-2004 gg.) [The rise and development of workforce capacity in Tuva (1921-2004)]: Diss.... Candidate of History. Irkutsk. 215 p. (In Russ.).

Sozdanie suverennogo gosudarstva v Tsentre Azii. Protokoly khuralov 1921 goda. K 70-letiiu obrazovaniia Respubliki Tannu Tyva ulus [Creating a sovereign state in the center of Asia. Protocols of khurals held in 1921. Published for the 70th anniversary of the creation of the Republic of Tannu-Tuva ulus] (1991) / comp. by V. A. Dubrovskii. Bai-Khaak, s. n. 96 p. (In Russ.).

Submission date: 15.07.2021. 